\title{
Effect of Antioxidants on Arsenite Exposed Porcine Embryonic Development
}

\author{
Han-Su Kim ${ }^{1, \$}$, Yu-Sub Lee ${ }^{1,}$, Sang-Hee Lee ${ }^{2}$, Hee-Tae Cheong ${ }^{3}$, Choon-Keun Park ${ }^{1}$, \\ Seunghyung Lee ${ }^{1, \uparrow}$ and Boo-Keun Yang ${ }^{1, \dagger}$ \\ ${ }^{1}$ College of Animal Life Sciences, ${ }^{2}$ Institute of Animal Resources, and ${ }^{3}$ School of Veterinary Medicine, \\ Kangwon National University, Chuncheon 24341, Korea
}

This study was to investigate the role of antioxidants on development in arsenite exposed porcine embryos. Oocytes were collected from porcine ovary, and then matured for $44 \mathrm{~h}$. Maturated oocytes were incubated with sperm for $6 \mathrm{~h}$, and fertilized oocytes with sperm (embryos) cultured for $48 \mathrm{~h}$. After, embryos were culture with arsenite and/or antioxidants (melatonin, silymarin, curcumin and vitamin) for $120 \mathrm{~h}$. Formation of pre-morulae, morulae and blastosysts rate was measured using microscope. In results, 10,100 and $100 \mathrm{nM}$ arsenite significantly decreased morulae and blastocysts formation compared to control in pigs $(P<0.05) .10 \mu \mathrm{M}$ silymarin and $100 \mu \mathrm{M}$ vitamin $\mathrm{E}$ increased blastocyst formation compared to $10 \mathrm{nM}$ arsenite exposed embryos, but there were no significantly among the treatment, and $1 \mathrm{nM}$ melatonin and $5 \mu \mathrm{M}$ curcumin did not influence blastocysts formation in $10 \mathrm{nM}$ arsenite exposed embryos. In summary, arsenite decreased embryo development, $10 \mu \mathrm{M}$ silymarin, $100 \mu \mathrm{M}$ vitamin $\mathrm{E}, 1 \mathrm{nM}$ melatonin and $5 \mu \mathrm{M}$ curcumin had no positive effect to blastocyst formation in arsenite exposed porcine embryos. Therefore, we suggest that little arsenite may have negative effect to embryo development, and silymarin, vitamin E, melatonin and curcumin could not rescue embryo development from damage by arsenite in pigs.

Key Words: Embryo development, Arsenite, Antioxidants, Pigs

산업의 발전은 생명체에게 환경오염물질을 노출하게 되 는 계기가 되었으며, 이러한 물질의 노출은 생명체의 질 병 유발과 건강을 악화시키는 원인이 되었다. 여러 종류 의 환경오염물질 중 하나인 arsenic (As)은 금속과 비금속 물질의 특성을 모두 가지고 있는 준금속물질로 알려져 있 다. As는 공업에서 유리 제조 시 탈색수지 및 반도체 제품 등에서 이용되며, 농업에서 건조제 및 고엽제 등으로 사 용되었다(Flora, 2016). As는 결합하는 이온의 종류에 따라 독성이 달라지게 되는데, 일반적으로 arsenite는 arsenate보
다 독성이 높은 것으로 보고되었다(Petrick et al., 2000). 산 업부분에서의 As는 유리 및 금속공업 제조 중에 발생하 여 생명체로 흡수된다는 보고가 있으며, 일반적으로 생명 체에게는 주로 지하수를 통한 음용수의 경우로 노출된다 (Guanet al., 2012). As에 장기적으로 노출될 경우 심혈관, 신경, 폐, 간, 소화기관, 피부 및 당뇨병에 유해한 영향을 주는 것으로 보고되었으며(Navas-Acien et al., 2006), 단기간 노출되었을 때 안구통증, 전신피로, 인후염, 두통, 구토 및 복통 등의 증상이 보고된 바 있다(Kinoshita et al., 2004).

*Received: January 30, 2017 / Revised: March 16, 2017 / Accepted: March 17, 2017

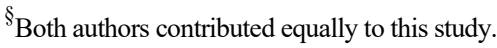

${ }^{\dagger}$ Corresponding author: Boo-Keun Yang. College of Animal Life Sciences, Kangwon National University, Chuncheon 24341, Korea. Tel: +82-33-250-8623, Fax: +82-33-259-5572, e-mail: bkyang@kangwon.ac.kr

${ }^{\dagger}$ Corresponding author: Seunghyung Lee. College of Animal Life Sciences, Kangwon National University, Chuncheon 24341, Korea. Tel: +82-33-250-8637, Fax:+82-33-259-5574, e-mail: s.lee@kangwon.ac.kr

(C) The Korean Society for Biomedical Laboratory Sciences. All rights reserved.

@ This is an Open Access article distributed under the terms of the Creative Commons Attribution Non-Commercial License (http://creativecommons.org/licenses/by-nc/3.0/) which permits unrestricted non-commercial use, distribution, and reproduction in any medium, provided the original work is properly cited. 
이러한 As는 동물의 번식능력에도 악영향을 미친다는 보고가 있으며, 실제로 $\mathrm{As}$ 에 노출된 암컷 쥐에서 estradiol, luteinizing hormone (LH) 및 follicle stimulating hormone (FSH) 의 호르몬 수치가 감소(Chattopadhyay et al., 2001; Chatterjee 와 Chatterji, 2010)하였으며, 수컷 쥐에서는 정자의 농도 감소 및 기형이 발생하였고, 정소의 무게가 감소였다는 보 고가 있다(Jana et al., 2006; Li et al., 2012). 또한 뇌하수체 성선자극 및 대사 호르몬의 유전자의 발현을 억제하여 내 분비계의 이상을 일으키는 것으로 보고되었다(Barr et al., 2009; Ciarrocca et al., 2012). 따라서 As는 동물의 번식기관 장애 및 호르몬의 분비를 교란시키는 물질로 분류하고 있 기 때문에 생식세포에서의 As에 대한 연구가 필요한 실정 이다.

일반적으로 세포 내 과도한 산화스트레스 및 활성산소 의 증가는 세포의 생존율을 감소시킬 뿐만 아니라 DNA 의 절단 증가와 같은 생리학적 현상을 유발한다(Cohen et al., 2006). As는 세포의 산화스트레스 유도, 활성산소 초과 생성 및 지질과산화를 증가시키며, 세포의 항산화 기능을 감소시킨다(Cohen et al., 2006). 따라서 As는 세포 내 산화 스트레스 및 활성산소를 증가시켜 세포 대사 감소 및 사 멸을 유도하여 DNA 손상 및 유전독성을 유발한다(Davies, 1999). 이뿐만 아니라 As는 쥐 배아의 활성산소 증가 및 항산화효소를 감소시켜 미토콘드리아의 활성을 감소시키 고 배아의 발달을 감소시킨다는 연구결과가 보고되었다 (Han et al., 2011). 하지만 As가 돼지의 배아 발달에 미치 는 영향에 대한 연구는 아직 부족한 실정이다.

항산화제는 산화스트레스로 인한 세포의 활성산소의 과 잉생성을 억제하며, 세포를 보호하는 중요한 역할을 한다 고 알려져 있기 때문에 항산화제를 이용한 배아의 수정 률 및 발달율을 향상시키는 연구는 지속적으로 진행되어 왔다(Truong et al., 2016). 특히 항산화제로 알려진 melatonin (Rodriguez-Osorio et al., 2007), silymarine (Kim et al., 2008), curcumin (Kim et al., 2010) 및 vitamin E (Gajda et al., 2008) 는 돼지 수정란 발달에 긍정적인 효과를 나타낸다고 알려 져 있다. 따라서 본 실험은 As가 돼지의 수정란 발달율에 미치는 영향과 $\mathrm{As}$ 에 의해 감소된 돼지 수정란의 발달율에 대한 melatonin, silymarin, curcumin 및 vitamin $\mathrm{E}$ 의 효과에 대해 연구를 실시하였다.

모든 동물실험은 강원대학교 동물실험윤리위원회의 승 인(KIACUC-09-0139)을 거쳤으며, 실험에 사용된 난소는 도축된 미경산돈에서 채취하였으며 $37^{\circ} \mathrm{C}$ 의 멸균 생리식염 수 용액에 보관하여, 2시간 이내에 실험실로 운반하였으
며, 난자의 성숙은 Lee et al. (2015)의 방법에 따라 수행 하였다. 운반된 난소는 생리식염수로 2 3회 세척 후, 난 포 내 3 5 mm 크기의 미성숙 난포란을 18 gauge의 주사 바늘을 이용하여 채취하였다. 난포란은 실체현미경(Nikon, Japan)을 이용하여 세포질 상태가 양호하며, 난구세포가 난자 주위에 균일하게 부착된 것을 회수하였으며, D-PBS 에 $0.1 \%$ polyvinyl alcohol (PVA)이 첨가된 용액(D-PBS$\mathrm{PVA})$ 을 이용하여 2회 세척 후 실험에 사용하였다. 미성 숙된 난포란를 성숙시키기 위하여 기본배양액(TC-199)에 $10 \%$ porcine follicular fluid, $0.5 \mu \mathrm{g} / \mathrm{mL}, \mathrm{FSH}, 0.5 \mu \mathrm{g} / \mathrm{mL} \mathrm{LH}$, $10 \mathrm{IU} / \mathrm{mL}$ human chorionic gonadotrophin (hCG) 및 $10 \mathrm{ng} / \mathrm{mL}$ epithelial growth factor (EGF)를 첨가한 배양액을 이용하여 미성숙 난자-난구세포 복합체를 $5 \% \mathrm{CO}_{2}, 38^{\circ} \mathrm{C}$ 조건 하에 서 22시간 배양한 후 $\mathrm{pFF}$ 와 호르몬을 제거한 TC-199 배 양액에서 22시간 동안 추가적으로 배양하였다.

체외수정을 위한 modified tris buffer medium (mTBM) 기본액배양액에 $2 \mathrm{mg} / \mathrm{mL}$ 의 bovine serum albumin (BSA)를 첨가하여, 배양접시 내에 $50 \mu \mathrm{L}$ 의 소적을 만든 후, 각각 15 개의 성숙된 난포란을 선별하여 소적으로 옮겨 넣었다. 체외수정을 위한 정자는 $\mathrm{mTBM}$ 으로 $2 \times 10^{7}$ 정자 $/ \mathrm{mL}$ 의 농도로 희석시킨 $50 \mu \mathrm{L}$ 의 정자부유액을 난포란이 옮겨진 소적에 삽입하여 체외수정을 실시하였다. 체외수정 6 8 시간 후 $4 \mathrm{mg} / \mathrm{mL} \mathrm{BSA}$ 가 첨가된 PZM-3 (Yoshioka et al., 2002) 배양액으로 3회 이상 세척 후 동일 배양액 내에서 48시간 동안 배양을 실시한 후 생산된 2 8세포기의 체외 수정란을 실험에 사용하였다(Lee et al., 2015).

체외수정 후 생산된 2 8세포기 체외수정란을 선별하여 $\mathrm{BSA}$ 가 첨가된 PZM-3의 배양액에 $1,5,10,100$ 및 1,000 $\mathrm{nM}$ arsenite를 첨가한 후 120 시간 동안 배양한 뒤 실체현 미경(Nikon, Japan)을 이용하여 체외수정란의 pre-morulae, morulae 및 blastocyst의 비율을 관찰하였다. 또한 2 8세포 기의 체외수정란은 $10 \mathrm{nM}$ arsenite와 $1 \mathrm{nM}$ melatonin (Jang et al., 2010), $10 \mu \mathrm{M}$ silymarin (Eskandari et al., 2016), $5 \mu \mathrm{M}$ curcumin (Jang et al., 2009) 및 $100 \mu \mathrm{M}$ vitamin E (Tvrdá et al., 2013)를 함께 첨가된 PZM-3 배양액을 이용하여 120시간 동안 배양한 뒤 체외수정란의 발육을 조사하였다.

본 실험에서 얻어진 결과의 값은 SAS 9.2를 이용하여 통계분석 하였으며, Duncan's Multiple Range Test 방법으로 첨가구간의 유의성을 검정하였고, $P$ 값이 0.05 수준 이상 인 것을 통계적 유의성이 있는 것으로 판정하였다.

산화스트레스는 수정란의 발달율을 감소시킬 뿐만 아 니라 DNA 손상 및 배반포 발달성적을 감소시키기 때문 
에 수정란 발달에 있어 산화스트레스를 감소시키는 연구 가 꾸준히 진행되고 있다(Qian et al., 2016). 수정란의 산화 스트레스를 증가시켜 발육성적을 감소시키는 As의 부정 적인 영향을 억제시키기 위해 항산화제를 역할에 대한 연구가 필요한 실정이기 때문에 본 연구에서는 돼지의 미 성숙 난포란을 체외에서 성숙 및 수정시켜 생산된 2 8세 포기의 체외수정란을 실험에 사용하였다. 또한 수정란 배양액에 산화스트레스를 유발하는 arsenite와 항산화제인 melatonin, silymarin, curcumin 및 vitamin $\mathrm{E}$ 를 첨가하여 체 외수정란의 발육성적에 미치는 영향을 검토하였다.

돼지 2 8세포기의 체외수정란에 있어 arsenite가 발육 성적에 미치는 결과는 Table 1에 나타내었다. $10 \mathrm{nM}$ 이상 의 arsenite를 첨가하였을 때, 상실배 이전의 수정란(premorulae)의 비율이 대조구에 비하여 유의적으로 증가하는 것을 확인하였으며, 상실배(morulae)는 $100 \mathrm{nM}$ 이상의 arsenite를 첨가하였을 때 유의적으로 감소하는 것을 확인 하였다 $(P<0.05) .1$ 및 $5 \mathrm{nM}$ arsenite는 돼지의 상실배 이전
및 상실배 발육성적에 큰 영향을 끼치지 않는 것으로 판 단되지만, 쥐의 경우 $4 \mu \mathrm{M}$ arsenite는 수정란의 발달율을 감소시킬 뿐만 아니라 비정상적인 수정란의 비율을 증가 시키며 수정란 내의 DNA를 손상시킨다고 알려져 있다 (Pérez-Pastén 등, 2006). 본 실험에서 이용한 돼지 체외수 정란의 경우 $10 \mathrm{nM}$ 이상의 arsenite 처리구에서 발육성적 이 감소되었기 때문에 arsenite가 처리된 돼지 수정란의 $\mathrm{DNA}$ 는 손상되었다고 판단되고 이러한 결과는 수정란의 발육성적을 야기시켰을 것이라 추측된다. 하지만 arsenite 에 대한 수정란 발육의 영향은 동물 종에 따라 차이가 있 을 것이라 판단되며, 정확한 arsenite 농도 구배차이에 의 한 돼지 수정란의 발육성적에 대한 연구결과가 필요하다 고 판단된다. 배반포(balstocyst)의 비율은 $10 \mathrm{nM}$ 이상의 arsenite를 첨가하였을 때 유의적으로 감소하였으며, 상실 배와 배반포의 합계 역시 $10 \mathrm{nM}$ 이상의 arsenite를 첨가하 였을 때 유의적으로 감소하는 것을 확인하였다 $(P<0.05)$. 특히 10,100 및 $1,000 \mathrm{nM}$ arsenite를 처리한 수정란에서는

Table 1. Effect of arsenite on embryo development in pigs

\begin{tabular}{cccccc}
\hline \hline \multirow{2}{*}{$\begin{array}{c}\text { Arsenite } \\
(\mathrm{nM})\end{array}$} & $\begin{array}{c}\text { No. of } \\
\text { embryos }\end{array}$ & \multicolumn{3}{c}{ No. of embryos developed to (\%) } & \multirow{2}{*}{$\begin{array}{c}\text { Morulae plus } \\
\text { Blastocysts (\%) }\end{array}$} \\
\cline { 3 - 5 } & 165 & $97(58.7 \pm 3.4)^{\mathrm{c}}$ & $33(20.6 \pm 6.1)^{\mathrm{abc}}$ & $35(20.7 \pm 3.2)^{\mathrm{a}}$ & $68(41.3 \pm 3.4)^{\mathrm{a}}$ \\
1 & 135 & $83(60.9 \pm 4.4)^{\mathrm{c}}$ & $33(25.1 \pm 4.6)^{\mathrm{ab}}$ & $19(13.9 \pm 2.0)^{\mathrm{bc}}$ & $52(39.1 \pm 4.4)^{\mathrm{a}}$ \\
5 & 135 & $77(56.3 \pm 5.0)^{\mathrm{c}}$ & $38(28.6 \pm 3.4)^{\mathrm{a}}$ & $20(15.1 \pm 1.7)^{\mathrm{ab}}$ & $58(43.7 \pm 5.0)^{\mathrm{a}}$ \\
\hline 10 & 165 & $119(72.2 \pm 1.1)^{\mathrm{b}}$ & $25(15.4 \pm 1.9)^{\mathrm{bc}}$ & $21(12.4 \pm 1.8)^{\mathrm{bc}}$ & $46(27.8 \pm 1.1)^{\mathrm{b}}$ \\
100 & 168 & $134(79.7 \pm 1.0)^{\mathrm{ab}}$ & $20(12.3 \pm 2.9)^{\mathrm{c}}$ & $14(8.1 \pm 2.2)^{\mathrm{cd}}$ & $34(20.3 \pm 1.0)^{\mathrm{bc}}$ \\
1000 & 168 & $147(87.3 \pm 3.0)^{\mathrm{a}}$ & $14(8.5 \pm 2.6)^{\mathrm{c}}$ & $7(4.2 \pm 0.5)^{\mathrm{d}}$ & $21(12.7 \pm 3.0)^{\mathrm{c}}$ \\
\hline
\end{tabular}

Data are presented as the mean \pm SEM. ${ }^{\text {a-d }}$ values in same column with different letters mean significant difference $(P<0.05)$.

Table 2. Effect of melatonin, silymarin, curcumin and vitamin $\mathrm{E}$ on development in exposed porcine embryo by $10 \mathrm{nM}$ arsenite

\begin{tabular}{|c|c|c|c|c|c|c|}
\hline \multirow{2}{*}{\multicolumn{2}{|c|}{ Treatments }} & \multirow{2}{*}{$\begin{array}{l}\text { No. of } \\
\text { embryos }\end{array}$} & \multicolumn{3}{|c|}{ No. of embryos developed to (\%) } & \multirow{2}{*}{$\begin{array}{l}\text { Morulae plus } \\
\text { Blastocysts (\%) }\end{array}$} \\
\hline & & & Pre-morulae & Morulae & Blastocysts & \\
\hline & ntrol & 63 & $29(46.8 \pm 3.7)^{\mathrm{b}}$ & $22(34.2 \pm 3.1)^{\mathrm{a}}$ & $12(18.9 \pm 0.7)^{\mathrm{a}}$ & $34(53.1 \pm 3.7)^{\mathrm{a}}$ \\
\hline Arse & te $10 \mathrm{nM}$ & 60 & $47(78.7 \pm 1.9)^{\mathrm{a}}$ & $13(21.3 \pm 1.9)^{b}$ & $0(0.0 \pm 0.0)^{\mathrm{b}}$ & $13(21.3 \pm 1.9)^{b}$ \\
\hline \multirow{4}{*}{$\begin{array}{l}\text { Arsenite } \\
10 \mathrm{nM}\end{array}$} & Melatonin & 60 & $51(85.6 \pm 3.2)^{\mathrm{a}}$ & $9(14.5 \pm 3.3)^{\mathrm{b}}$ & $0(0.0 \pm 0.0)^{\mathrm{b}}$ & $9(14.5 \pm 3.3)^{b}$ \\
\hline & Silymarin & 60 & $44(73.2 \pm 5.9)^{\mathrm{a}}$ & $14(23.2 \pm 4.1)^{\mathrm{b}}$ & $2(3.6 \pm 1.9)^{\mathrm{b}}$ & $16(26.8 \pm 5.9)^{\mathrm{b}}$ \\
\hline & Curcumin & 59 & $49(83.9 \pm 4.6)^{\mathrm{a}}$ & $10(16.1 \pm 4.6)^{b}$ & $0(0.0 \pm 0.0)^{\mathrm{b}}$ & $10(16.1 \pm 4.6)^{b}$ \\
\hline & Vitamin E & 62 & $51(81.8 \pm 4.6)^{\mathrm{a}}$ & $10(16.1 \pm 3.3)^{b}$ & $1(2.1 \pm 2.1)^{b}$ & $11(18.2 \pm 4.6)^{\mathrm{b}}$ \\
\hline
\end{tabular}

Melatonin, $1 \mathrm{nM}$ melatonin; Silymarin, $10 \mu \mathrm{M}$ silymarin; Curcumin, $5 \mu \mathrm{M}$ curcumin; and Vitamin E, $100 \mu \mathrm{M}$ vitamin E. Data are presented as the mean \pm SEM. ${ }^{\text {a, }}$ values in same column with different letters mean significant difference $(P<0.05)$. 
대조구에 비하여 발육성적이 현저하게 감소하였는데 실 제로 25,50 및 $250 \mathrm{nM}$ arsenite에 장기간 노출된 햄스터 체외수정란은 발육과 생존율이 감소하였으며, DNA 변형 으로 인한 세포의 기형 및 사멸이 증가하였다는 연구결과 가 있다(Unis 등, 2009). 따라서 $100 \mathrm{nM}$ 이상의 arsenite는 동물의 수정란 발달에 매우 심각한 악영향을 미칠 뿐 아 니라 수정란의 DNA 손상 및 활성산소를 증가시킬 것이 라 판단된다.

$10 \mathrm{nM}$ arsenite와 $1 \mathrm{nM}$ melatonin, $10 \mu \mathrm{M}$ silymarin, $5 \mu \mathrm{M}$ curcumin 및 $100 \mu \mathrm{M}$ vitamin $\mathrm{E}$ 를 함께 첨가한 수정란 배양 액(PZM-3)을 이용하여 120시간 동안 배양된 2 8세포기의 돼지 수정란의 발육성적은 Table 2 에 나타내었다. Table 2 에 나타낸 바와 같이 상실배기 이상의 발육성적은 대조구 와 비교하여 $10 \mathrm{nM}$ arsenite 단독 처리구에서 유의적으로 감소하였으며 $(P<0.05), 10 \mathrm{nM}$ arsenite와 $10 \mu \mathrm{M}$ silymarin을 함께 첨가한 처리구에서 상실배와 배반포 비율이 증가하 였지만 유의적인 차이는 나타나지 않았다. 또한 상실배와 배반포 비율은 $10 \mathrm{nM}$ arsenite 처리구와 $1 \mathrm{nM}$ melatonin, $10 \mu \mathrm{M}$ silymarin, $5 \mu \mathrm{M}$ curcumin 및 $100 \mu \mathrm{M}$ vitamin $\mathrm{E}$ 을 $10 \mathrm{nM}$ arsenite와 공동으로 첨가한 처리구 사이에는 유의 적인 차이가 나타나지 않았다.

일반적인 체외 환경에 있어 melatonin (Rodriguez-Osorio et al., 2007), silymarine (Kim et al., 2008), curcumin (Kim et al., 2010) 및 vitamin E (Gajda et al., 2008)는 수정란의 활성산 소 및 산화스트레스를 감소시켜 발달율을 향상시킨다고 알려져 있다. 또한 일반적인 체외 환경에서 돼지 수정란 발달을 향상시킬 수 있는 $1 \mathrm{nM}$ melatonin, $10 \mu \mathrm{M}$ silymarin, $5 \mu \mathrm{M}$ curcumin 및 $100 \mu \mathrm{M}$ vitamin $\mathrm{E}$ 를 본 연구에 이용하였 지만, $10 \mathrm{nM}$ arsenite에 의해 감소된 수정란 발달율을 회복 시키기에는 한계가 있는 것으로 판단된다. 따라서 arsenite 에 의해 감소된 돼지 수정란의 발달율을 회복시키기 위해 서는 일반적인 환경에서보다 고농도의 항산화제를 이용한 실험이 필요하다고 판단된다.

종합적으로 arsenite는 돼지 수정란의 발육성적을 감소 시키는 것을 확인하였으며, 본 실험에서 사용된 항산화제 의 농도를 이용하였을 때에는 $10 \mathrm{nM}$ arsenite에 의해 손상 을 입은 돼지 수정란의 발달율을 회복시킬 수 없었다. 결 론적으로 산화스트레스 및 활성산소를 증가시키는 arsenite 는 돼지 수정란의 발육성적에도 부정적인 영향을 미치 는 것을 확인하였으며, 항산화제인 melatonin, silymarin, curcumin 및 vitamin $\mathrm{E}$ 는 arsenite에 노출된 돼지 체외수정 란 발육성적에 영향을 미치지 않은 것으로 사료된다.

\section{Conflict of interest}

The authors declare that there is no conflict of interest that could be perceived as prejudicing the impartiality of the research reported.

\section{REFERENCES}

Barr FD, Krohmer LJ, Hamiton JW, Sheldon LA. Disruption of histone modification and CARM1 recruitment by arsenic represses transcription at glucocorticoid receptor-regulated promoters. PloS One. 2009. 4: e6766.

Chatterjee A, Chatterji U. Arsenic abrogates the estrogen-signaling pathway in the rat uterus. Reproductive Biology and Endocrinology. 2010. 8: 80.

Chattopadhyay S, Ghosh S, Debnath J, Ghosh D. Protection of sodium arsenite-induced ovarian toxicity by coadministration of L-ascorbate (Vitamin C) in mature Wistar strain rat. Archives of Environmental Contamination and Toxicology. 2001. 41: 83-89.

Ciarrocca M, Tomei F, Caciari T, Cetica C, Andre JC, Fiaschetti M, Schifano MP, Scala B, Scimitto L, Tomei G, Sancini A. Exposure to Arsenic in urban and rural areas and effects on thyroid hormones. Inhalation Toxicology. 2012. 24: 589-598.

Cohen SM, Amold LL, Eldan M, Lewis AS, Beck BD. Methylated arsenicals the implications of metabolism and carcinogenicity studies in rodents to human risk assessment. Critical Reviews in Toxicology. 2016. 36: 99-133.

Davies KJ. The broad spectrum of responses to oxidants in proliferating cells: a new paradigm for oxidative stress. IUBMB Life. 1999. 48: 41-47.

Eskandari F, Momeni HR. Protective effect of silymarin on viability, motility and mitochondrial membrane potential of ram sperm treated with sodium arsenite. International Journal of Reproductive BioMedicine. 2016. 14: 397-402.

Flora SJ. Arsenic and dichlorvos: Possible interaction between two environmental contaminants. Journal of Trace Elements in Medicine and Biology. 2016. 35: 43-60.

Gajda B, Bryła M, Smorąg Z. Effects of protein source, vitamin E and phenazine ethosulfate on developmental competence and quality of porcine embryos cultured in vitro. Folia Biologica. 2008. 56: 57-63.

Guan X, Du J, Meng X, Sun Y, Sun B, Hu Q. Application of titanium dioxide in arsenic removal from water: a review. Journal of Hazardous Materials. 2012. 215: 1-16. 
Han ZJ, Song G, Cui Y, Xia HF, Ma X. Oxidative stress is implicated in arsenic-induced neural tube defects in chick embryos. International Journal of Developmental Neuroscience. 2011. 29: 673-680.

Jana K, Jana S, Samanta PK. Effects of chronic exposure to sodium arsenite on hypothalamo-pituitary-testicular activities in adult rats: possible an estrogenic mode of action. Reproductive Biology and Endocrinology. 2006. 4: 9.

Jang HY, Kim YH, Cheong HT, Kim JT, Park IC, Park CK, Yang BK. Curcumin attenuates hydrogen peroxide induced oxidative stress on semen characteristics during in vitro storage of boar semen. Reproductive and Developmental Biology. 2009. 33: 99-105.

Jang HY, Kong HS, Choi KD, Jeon GJ, Yang BK, Lee CK, Lee HK. Effects of melatonin on gene expression of IVM/IVF porcine embryos. Asian-Australasian Journal of Animal Sciences. 2010. 18: $17-21$

Kim HS, Jang HY, Kim HS, Kim TH, Park IC, Cheong HT, Kim JT, Park CK, Yang BK. Effects of antioxidants against arsenite induced damage on sperm characteristics and development of IVM/IVF embryos in pig. The 35th Annual Meeting of the Korean Society of Reproductive and Development Biology. 2010.

Kim YH, Jang HY, Kim HS, Ji SJ, Kim JT, Park CK, Cheong HT, Yang BK. Effects of silymarin on boar semen characteristics and porcine IVMI/IVF embryos. The 33th Annual Meeting of the Korean Society of Reproductive and Devlopment Biology. 2008.

Kinoshita H, Hirose Y, Tanaka T, Yamazaki Y. Oral arsenic trioxide poisoning and secondary hazard from gastric content Annals of Emergency Medicine. 2004. 44: 625-627.

Lee SH, Park CK. Effect of magnetized extender on sperm membrane integrity and development of oocytes in vitro fertilized with liquid storage boar semen. Animal Reproduction Science. 2015. 154: 86-94.

Li Y, Wang M, Piao F, Wang X. Subchronic exposure to arsenic inhibits spermatogenesis and down-regulates the expression of Ddx3y in testis and epididymis of mice. Toxicological
Sciences. 2012. 128: 482-489.

Navas-Acien A, Silbergeld EK, Streeter RA, Clark JM, Burke TA, Guallar E. Arsenic exposure and type 2 diabetes: A systematic review of the experimental and epidemiologic evidence. Environmental Health Perspectives. 2006. 114: 641-648.

Perez-Pasten R, Martinez-Galero E, Garduno-Siciliano L, Lara IC, Cevallos GC. Effects of dimethylsulphoxide on mice arseniteinduced dysmorphogenesis in embryo culture and cytotoxicity in embryo cells. Toxicology Letters. 2006. 161: 167-173.

Petrick JS, Ayyala-Fierro F, Cullen WR, Carter DE, Vasken Aposhian H. Monomethylarsonous acid (MMAIII) is more toxic than arsenite in Chang human hepatocytes. Toxicology and Applied Pharmacology. 2000. 163: 203-207.

Qian D, Li Z, Zhang Y, Huang Y, Wu Q, Ru G, Chen M, Wang B. Response of mouse zygotes treated with mild hydrogen peroxide as a model to reveal novel mechanisms of oxidative stress-induced injury in early embryos. Oxidative Medicine and Cellular Longevity. 2016: 1521428.

Rodriguez-Osorio N, Kim I, Wang H, Kaya A, Memili E. Melatonin increases cleavage rate of porcine preimplantation embryos in vitro. Journal of Pineal Research. 2007. 43: 283-288.

Sung HJ, Jeong YJ, Kim J, Jung E, Jung JH. Soybean peptides induce apoptosis in HeLa cells by increasing oxidative stress. Biomedical Science Letters. 2015. 21: 77-83.

Truong TT, Soh YM, Gardner DK. Antioxidants improve mouse preimplantation embryo development and viability. Human Reproduction. 2016. 31: 1445-1454

Tvrdá E, Lukác N, Lukácová J, Knazická Z, Massányi P. Stimulating and protective effects of vitamin $\mathrm{E}$ on bovine spermatozoa. Journal of Microbiology, Biotechnology and Food Sciences. 2013. 2: 1386-1395.

Unis D, Osbome C, Diawara MM. Arsenite exposure compromises early embryonic development in the Golden hamster. Reproductive Toxicology. 2009. 28: 329-334.

Yoshioka K, Suzuki C, Tanaka A, Anas IM, Iwamura S. Birth of piglets derived from porcine zygotes cultured in a chemically defined medium. Biology of Reproduction. 2002. 66: 112-119. 